DOI: 10.2478/linpo-2014-0011

\title{
Zabrocki's structural phonetics in the case study of velar POA assimilation in Latinate prefixation in RP English
}

\author{
Malgorzata Haladewicz-Grzelak \\ Studium Języków Obcych, Politechnika Opolska, haladewicz@gmail.com
}

\begin{abstract}
Małgorzata Haładewicz-Grzelak. Zabrocki's structural phonetics in the case study of velar POA assimilation in Latinate prefixation in RP English. The Poznan Society for the Advancement of the Arts and Sciences. PL ISSN 0079-4740, ISBN 978-83-7654-388-8, pp. 19-28

Zabrocki understood structural phonetics as a branch of phonetics concerned with analyzing acodal (substantial) systems (cf. Bańczerowski 1980: 13). In this theory, each sound has a specific acoustic and articulatory substance. Zabrocki constructed linear substantial sound structures based on measuring the amount of substance implied in the articulation. Diachronic structural phonetics, in turn, is the application of synchronically defined phonetic and acoustic relations to the study of language change. This paper investigates a synchronic scenario for velar POA assimilation in Latinate prefixation in English and tests the findings against the tenets of Zabrocki's theory. The results show that Zabrocki's structural phonetics perfectly accounts for the empirical findings. The corpus of investigation is comprised of realizations of all RP English Latinate prefixes ending with /n/, collected from various pronunciation dictionaries (online and paper). As a collateral corpus, recordings of two native speakers of English were made in which they produced some of the corpus material, as well as nonce words and unusual lexemes not listed in pronunciation dictionaries.
\end{abstract}

Key words: Zabrocki's structural phonetics, English prefixation, POA velar assimilation

\section{Background}

Ludwik Zabrocki (1907-1977) elaborated his theory of (diachronic) structural phonetics in the 1950s. ${ }^{1}$ In many ways, it was revolutionary and ahead of his times. His views on phonological systems opposed both the Neogrammarian thought and the mainstream theories of his time: the Praguian, American and Danish (Hjemslev's glossematics) versions of structuralism. As the scholar himself points out, "functionalized substantial systems are systems of a hybrid nature. For [modelling] their internal structure physiological differences were assumed, which were to be an adequate equivalent of acoustic elements. As we have

1 All the translations from Polish and French in the text, my authorship, MHG. The reported analysis is part of a larger project on English prefixation (e.g. Haładewicz-Grzelak 2014, [submitted]), where a more detailed list of referential material can be found. 
noted earlier, this was an inconsequence, committed by all schools of structuralism" (Zabrocki 1960[1980]: 53). This paper puts to use the tenets of Zabrocki's structural phonetics to gain novel insights on English Latinate prefixation. It must be admitted that due to the early stage of the research, both the database complied and conclusions reached were of heuristic nature and definitely merit further investigation. However, the conclusions which the analysis enabled me to draw are to be thought of as a starting point and an invitation for further investigation of the relatively neglected topic of English prefixation. ${ }^{2}$

As Bańczerowski (1980) points out, substantial systems in Zabrocki's paradigm rely entirely on articulatory and acoustic differences in units of a language isolated in code structures. Moreover, the internal characteristics of such systems are specified immanently, and thus, the code structures of a given language are independent of functional differences within the units (Bańczerowski 1980: 14). To determine particular structural arrangements, Zabrocki distinguished several types of physiological substance: the mass of the articulator, the degree of the supraglottal aperture, the length of the articulatory path, the duration and place of articulation. A schematized, simplified system based on the value of the aperture of sounds according to Zabrocki's structural phonetics (1960[1980]: 56) is presented in Figure 1 as an example.

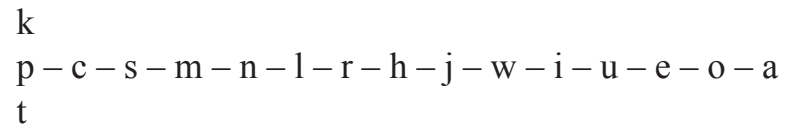

Figure 1: A simplified system based on the value of the aperture of sounds (adapted from Zabrocki 1960[1980: 56])

All other sounds can be subsequently incorporated into the structure. For example, /f/ would be placed between $/ \mathrm{s} /$ and $/ \mathrm{m} /$. For Zabrocki, a structure represents an ordering based on inherent features, such as the degree of aperture. A system, as opposed to a structure, is an ordering based on functional features. Zabrocki further defines structural mass as a potential element of force in a given consonantal group. Its value is determined by the structure of a given process. Differences in the values of the structural mass depend on the character of the structural binding with respect to the structure of the process. Hence it can be concluded that language-specific parameters determine the minimal requirements for the structural mass involved in specific clusters, both in terms of the ability to develop a particular binding and the resistance of these clusters to a given process (cf. Zabrocki 1960[1980]: 57). ${ }^{3}$

The present discussion is grounded in Zabrocki's research on the stability of the nasal element. To recall, for Zabrocki, not everything that takes place within phonetic change actually ensues from the phonetic level (Zabrocki 1962[1981]: 195). As Awedyk points out, "according to Zabrocki (1958) there are two types of processes: (1) primary (phonetic) and

2 Using Zabrocki 's model definitely does not imply disregard for subsequent work on nasals (A. Ginsberg's 'paradigm of ideas'). Tobias Scheer, referring to Chomsky's achievements describes the situation as 'reinventing the wheel' in phonology: more recent research uses similar categories or insights but under different names. For example, it is generally agreed (e.g. Ohala \& Ohala 1993) that the velar nasal is the most 'vowel-like' of all nasal stops, which is exactly what Zabrocki's model in the 1950s showed. There is nothing wrong with using and earlier reference for the same thought.

3 Zabrocki's insights on the motivation of sounds changes were successfully applied e.g. by Awedyk (1975) in a comparative study of umlaut and breaking. See also a discussion in Awedyk (2007). 
secondary (both phonological and phonetic)" (Awedyk 1975: 6). The action of the phonological plane is a secondary phenomenon resulting from the relation between the semantic plane and the mechanical, phonetic one (Zabrocki 1962[1981]: 178). In other words, phonetic evolution is modified by phonological factors: ${ }^{4}$ "C'est la reconnaissance de l'évolution phonétique en tant que procès fondamental qui permet de donner une base aux procès phonologiques ou bien a l'intervenion de la fonction morphologique. Il est impossible d'expliquer les résultats des changements phonétiques sans admettre l'intervention de la base phonologique" (Zabrocki 1962[1981]: 178). Thus, every phonic change is a result of the interplay of two planes: physiological-psychical and phonological. In this struggle, the phonological platform may be completely defeated (Zabrocki 1962[1981]: 196). Establishing the probability of changes within the realm of particular codal areas is one of the key problems for synchronic structural phonetics.

Zabrocki begins by providing a physiological and acoustic specification of nasal elements (cf. Zabrocki 1962[1981]: 192 for details). A major conclusion is that nasal stops are not just oral stops plus a nasal element, but separate sounds: one compact sound in the case of nasal stops, and two overlain articulations in nasal vowels. Languages generally do not make use of nasal spirants. As Zabrocki points out, this results from the fact that in fricative sounds the relation of the size of the resonators (oral to nasal) is very unpropitious: in the articulation of a nasal spirant too much air flows through the nasal resonator compared to the oral resonator. In this way, the acoustic effect of the nasal resonator dampens or blurs the acoustic effect of the oral resonator.

From the physiological and acoustic points of view, there must thus exist particular optimal proportions for the two resonating cavities (or of access therein). A detailed physiological analysis leads Zabrocki to determine a gradation of the 'propitiousness' for holding nasality on the basis of the structural arrangements he established in his structural phonetics. In other words, the codal structures allow one to draw conclusions about the stability of the nasal element. The results established by Zabrocki are shown in the graph in Figure 2 (right). Two poles were singled out by means of physiological criteria as the most propitious for holding nasality: one consists of stops and the other of vowels. There are two pluses on the side of the stops, and one on the side of the vowels, which leads stops to be acoustically and articulatorily more compact, uniform sounds, while nasal vowels always involve two separate, superimposed articulations; hence, stops are the most stable of all nasal sounds. Towards the lower areas of the graph, the physiological basis for holding nasality becomes less propitious (less stable). Such a system of sounds was built basing on the difference in the articulatory groove and concomitantly applying certain modifications by virtue of the arrangement of the size of the articulatory mass of the speech organs. The conclusion was that the narrower the sound in the respect to the articulatory opening, the less susceptible it is to acquiring nasality. This implies, for example, that nasality has a better existential base in the case of $/ \mathrm{r} /$ than $/ 1 /$, and better in the case of $/ 1 /$ than $/ z /$.

The next implication of such a codal arrangement regards the probability for loss of the nasal element. Zabrocki assumes that the elements with the highest position (that is, the structurally best 'containers' for holding nasality) should be the last to lose this nasality if

\footnotetext{
4 Zabrocki additionally motivates this claim by his insights on apophony and laryngeals, but this is beyond the scope of the present discussion.
} 
a set of conditions leading to the loss of nasality arises in a given language. Accordingly, the greatest probability for the elimination of nasality exists in spirants, followed by liquids, vowels and finally, stops. As Zabrocki emphasizes, this only relates to probability, not absolute physical laws. We cannot predict whether or not a given process will occur (Zabrocki 1962[1981]: 199). However, based on pre-established codal structures, we can single out areas of greater probability of the process occurring. Therefore, nasality can persist in the case of $/ \mathrm{u} /$ and $/ \mathrm{i} /$, while, from a phonetic perspective, nasality cannot persist in the case of /u/ and /i/, while dissapearing in the case of /a/ (Zabrocki 1962[1981]: 202). ${ }^{5}$ There is also an implicational gradation within groups. For example, nasal stops are differentiated with respect to the mass of closure. As Zabrocki's arrangement shows, $/ \mathrm{m} /$ has a greater articulatory mass than $/ \mathrm{n} /$, hence it is stronger and more stable. By implication, angma (velar nasal) has the greatest articulatory mass of all nasal stops. Fig. 2 (left) shows an attempt to create a 3D model of this asymmetry, which Zabrocki tried to render by means of the differentiation "++" / "+".

From the formal point of view, the ability to hold nasality is a classic example of a function's derivative: it is a measure of how the function changes as the input changes. In this case, we actually have two single variable functions; one variable with the closure mass, and another with the opening mass. Zabrocki enumerates the key parameters as closure, the homorganicity of place of articulation (POA henceforth), and voicing. This is also the reason for the relative difference in the positioning of particular sounds on the curve. The left hand side reflects the variable of the mass of closure as a function of a total articulatory mass (with respect to stops) and the right hand side - the degree of opening with regard to vowels.
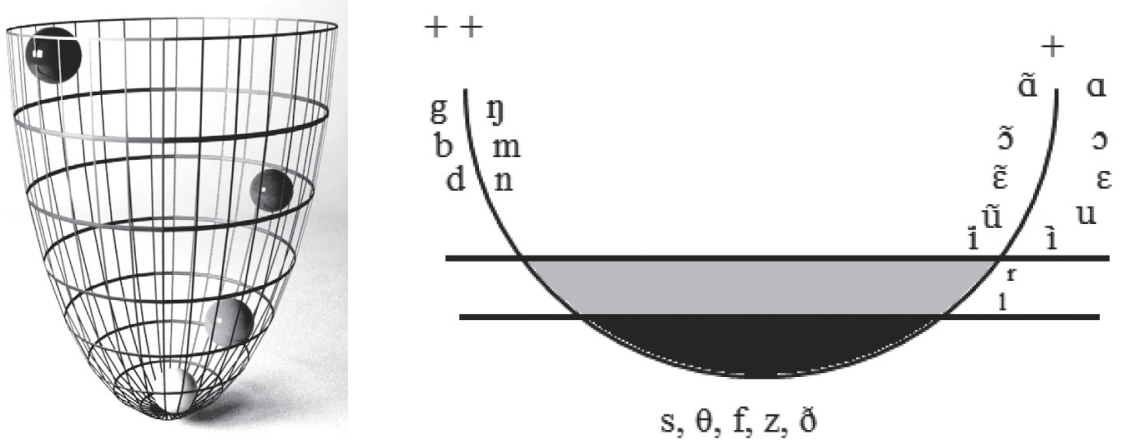

$\mathrm{s}, \theta, \mathrm{f}, \mathrm{z}, \mathrm{\sigma}$

Figure 2 (right panel): Zabrocki's graphic representations of the codal arrangements with respect to the stability of the nasal element in sounds (adapted from Zabrocki 1962[1981]: 194) with added IPA symbols. (left panel): 3D visualization of the articulatory substance and differences between the two poles (author: Aleksandra Grzelak)

Another natural conclusion from Zabrocki's codal arrangement is the stipulation that sounds with fewer propensities to hold nasally should also exert a negative influence on the preceding nasal segments. Thus, we should expect the weakening of the nasal element before spirants. Another crucial criterion for the stability of the nasal segment is the voice

5 Zabrocki admits on several occasions the possibility of gaps in the system; however, these gaps result from the intervention of extra-phonetic factors. 
status of the following sounds. As Zabrocki (Zabrocki 1962[1981]: 203) observes, the fact that nasal consonants mainly occur across languages as phonetically voiced implies that the position before voiced sounds can be seen as unfavourable. Finally, the unpropitious influence of a spirant will be greater if a lesser number of elements differentiates the spirant from the preceding nasal. In other words, homorganicity can be seen as unfavourable for the stability of the nasal element.

These points of reference, which Zabrocki established on synchronic-acoustic and articulatory grounds, are next verified on the diachronic level. Zabrocki assumes that if the tenets of structural phonetics are correct, the tendency should also show itself in the historic development of the phonic substance of languages. The propitious or unpropitious synchronic structure of sounds should be directly verified in the form of a lesser or greater stability of such sounds in their historic development. Areas of synchronically propitious or unpropitious structure in the nasals should be transformed in the diachronic dynamic into areas of lesser or greater probability of holding the nasal element (Zabrocki 1962[1981]: 204).

To this aim, Zabrocki traces the diachronic situation of the nasal segments in clusters through most IE languages and dialects. Diachronic data fully confirmed the synchronic arrangements - both in the case of the favourable and unfavourable pole of the arrangement. The law of the greater and lesser stability of the nasal elements, as well as of greater or lesser probability of changes depending on particular codal areas does not need to be authenticated within one or even within several languages. This becomes clearly evident only when a large number of languages or dialects is taken onto consideration. For example, a given language may show mainly the elimination of the nasal element before a spirant (e.g. Greek dialects) or before spirants and stops, but the nasal element cannot be eliminated before stops while it persists before spirants.

Finally, Zabrocki's data also included the split into voiced and voiceless contexts during the diachronic development of languages and dialects. In the case of both spirants and stops, the synchronic prediction was fully verified: the voicelessness of the following stop exerts a negative influence on the stability of the nasal segments (Zabrocki 1962[1981]: 240). This means that when nasals start to disappear before stops, they do so first before voiceless stops, and then before voiced ones. Zabrocki also corroborated diachronically the homorganicity of POA as a negative factor affecting the stability of the nasal element. For example, in Old Hindu, Avesta, (Persian), Greek, Latin and Celtic there was always the homorganic articulation of the nasal with the following stop. However, in Baltic and German this did not occur, hence the differences in terms of the stability of the nasal segment within these groups. Additionally, the fact that e.g. $/ \mathrm{n} /$ is weaker than $/ \mathrm{m} /$ was also corroborated in, e.g. Baltic.

\section{The issue of the velar POA assimilation in Latinate prefixation in English}

English affixation seems to be an obvious topic for study. There have been a number of works on affix ordering, and their behaviour with the respect to stress (e.g. Carr 1993; Rakić 2006; Chornogor 2006; Scheer 2011 for overview, discussion and detailed references). The majority of elaborations, however, focus only on suffixes: English prefixes are a relatively 
neglected field of analysis. Research usually concentrates on the taxonomic divide into Latinate (stress shifting or cohering affixes, that is, inducing the nasal POA assimilation) and non-cohering ones (stress neutral), where the assimilation is blocked. ${ }^{6}$

The present discussion was spurred by an observation by Chomsky \& Halle (1968: 419) who noticed the difference in the nasal assimilation of the pair such congress, Concord $[\mathrm{y}]$ and congressional / concordance $([\mathrm{n}]) .{ }^{7}$ When the prefix $\{$ con- $\}$ is stressed, POA assimilation is obligatory, but when there is no stress in $\{$ con- $\}$, the assimilation is usually blocked. For example, in congress - the nasal assimilated to the velar articulation, while in congressional the articulation is alveolar. ${ }^{8}$ In monomorphemic items containing the same sequences, assimilation is always obligatory (e.g. bronchus - bronchitis). To follow up on these findings, a combined dictionary search was performed, that is, a large variety of dictionary transcriptions and recordings - in both paper and electronic form - were checked. Also used were online sources for checking pronunciation (e.g. Forvo) and for in-depth specialized vocabulary searches. ${ }^{9}$ As additional support, recordings of realizations by two native speakers were used for sequences which did not appear in dictionaries, for nonce words (e.g. rhinegress), and to corroborate basic, dictionary versions. A tentative list of all possible Latinate and Greek prefixes was compiled, as in (1), and the contexts of the velar environment checked.

\begin{tabular}{|c|c|c|c|}
\hline a. & $\{$ an- (a-) $\}$ 'without, not' & h. & $\{$ phon- $\}$ 'sound' \\
\hline b. & $\{$ circum-\} 'around' & i. & $\{$ in, im- $\}$ 'not' \\
\hline c. & $\{$ idem- $\}$ 'the same' & $\mathrm{j}$. & $\{$ rhin- $\}$ 'nose', \\
\hline d. & $\{$ desm- $\}$, 'bind' & $\mathrm{k}$. & $\{$ sin-/ sys/ sym/syn-\} 'with, together' \\
\hline e. & \{quin-\} 'fifth', & 1. & $\{$ gyn-\} 'female' \\
\hline f. & $\{$ un- $\}$ (an OE prefix) 'not, opposite', & $\mathrm{m}$. & $\{$ pan-\} 'all, whole' \\
\hline g. & $\{$ uran-/ urano-\} 'heaven' or 'roof'. & n. & $\{$ xen- $\}$ 'strange' \\
\hline
\end{tabular}

6 For example, Booij says the following: "we might explain this by assuming that the domain of this rule of assimilation is the phonological word. The prefix -in can be considered as a cohering prefix and the prefix non-as a noncohering prefix. Hence, the rule of assimilation will apply only to the prefix in- since it forms one phonological word with the stem, a domain in which the assimilation rule can apply" (Booij 2012[2005]: 303).

7 Hoard (1971) built on this thought by proposing the explanation in terms of the difference in particular syllabification patterns: "Here the stress attracts the $g$ to the first syllable and gives the $\mathrm{y}$ in congress but stress attracts the $g$ to the second syllable in congressional, giving $n$ not $\mathrm{y}$ in the first syllable" (Hoard 1971: 136). The

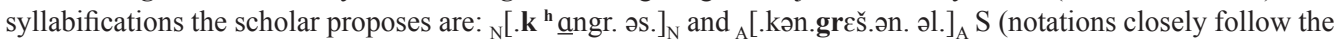
original] (Hoard 1971: 138). Also compare the representation in Anderson \& Jones (1972) and their term "maximalist syllable" (Anderson \& Jones 1977: 94).

8 Since the phenomenon was confirmed by an array of eminent phonologists (both American and British), starting from Noam Chomsky and Morris Halle, through James Hoard and later John Anderson and Charles Jones, I felt justified in assuming that the pattern is sufficiently salient to be subject to analysis as valid for English phonology.

9 E.g. Collins Cobuild English Language Dictionary. 1988. London: Klett; Jones, Daniel. 2003. Cambridge English Pronouncing Dictionary. Sixteenth Edition; Wells, J.C. 1990. Longman Pronounciation Dictionary. Harlow: Pearson Education; Dicconario de uso inglés - español Spanish-English. 1993. Madrid: SGEL-Educación; Longman Dictionary of Contemporary English. 1978/1981. Bath: Longman; Oxford English Dictionary on CD-ROM. (1992). (2nd edition.) Oxford: Oxford University Press; El Diccionario Oxford/The Oxford Spanish Dictionary. 1994. Oxford: Oxford University Press. Online sources: http://www.encyclo.co.uk; http://dictionary. reference.com; http://dictionary.cambridge.org; http://www.memidex.com; http://www.thefreedictionary.com; http://melodict.com/ http://www.yourdictionary.com; http://pl.forvo.com; www.macmillandictionary.pronunciation/british. 


\section{Discussion within the framework of structural phonetics}

The research yielded several unexpected findings. First of all, among the multitude of English prefixations ending in $/ \mathrm{n} /(/ \mathrm{m} /)$, the assimilatory contexts were verified only for two: $\{$ con- $\}$ and $\{$ syn- $\}$. Most sources indicated also an assimilated version for $\{$ pan- $\}$, as in pancreas but the pattern did not seem to be consistent enough. ${ }^{10}$ The prefix \{in-\} turned out to be of particular analytical interest. As mentioned in the introduction section, it is usually given as the epitome cohering prefix, and contrasted with $\{\mathrm{un}-\}$, which receives the status of an epitome non-cohering one (Level 2, see e.g. Scheer 2011: 6.2.5). However, as far as the velar POA assimilation is concerned, there seemed to be hardly any assimilations. (2) shows the juxtaposition of relevant realizations which I managed to access when the nasal was followed by a voiceless velar stop:

(2) a. incarnation/, Inka:'neIJən/; incongruity/, Inkəngr'u:Iti/

b. incarnate (adj.) /m 'ka:ntt/, incongruous /mn'kpygruəs/, incog /m'kpg/

c. income /' Inkım; 'ınkım/, incubate / 'mkjobert; 'Inkjobert/, incubus /'m, kjəbəs; 'ınk-/

d. incoming /' in, $\mathrm{k} \wedge \mathrm{min} /$, incomer /' $\mathrm{m}, \mathrm{k} \wedge \mathrm{ma/}$

e. ink/'mk/ inkling/'ınklın/, inky/'ınki/, Inca/'ınka/

The specification splits this data into various stress patterns. As can be seen, only 2(e), where etymologically $\{$ in- $\}$ is not a prefix, involves obligatory assimilation. Only under primary stress is there an optional possibility of an assimilated realization. (3) shows the parallel breakdown for the voiced contexts:

(3) a. ingrowing/, In' grounin/

b. ingress (v.)/In'gres/, ingratiatory/in' greI/rə,torI/, ingurgitate/In'gз-d3ə, tert/, ingulf /in'gnlf/

c. ingress (n.) /' Ingres/, ingoing /'m , gory/, ingrate/' Ingrert/, ingathering /'ıngæðərı/

d. inguinal /'ıngwinl/, Inge/ın/, Ingraham /'ıngriəm/, Ingham/'rnəm/, ingot /' rngət/, Ingoldsby /'inglzbi/, ingle /' $\mathrm{ingl} /{ }^{11}$

The data point to one crucial fact: similarly to (2)e, only in (3)d (where /ng/ is monomorphemic), was the assimilation obligatory. A dictionary (online and analogue) search did not indicate assimilation options even for the tonic syllable. As far as \{con- $\}$ is concerned, the relevant contests are as in (4):

${ }^{10}$ Pancreatic was realized in my native speaker database as the version/,pæn.kri'æt.Ik/ that is, with $\{$ pan- $\}$ under secondary stress.

11 My native speakers database, however, did not show any assimilation in $\{$ in $\}$ prefixation, regardless of the stress pattern or voicing status. The dictionary data thus seem to be less restricted. We also have to make a caveat that for this stage of the analysis I rejected the isolated notations which both for $\{$ un- $\}$ and $\{$ in- $\}$ prefix gave the velar across the board. 
(4) a. congregation /, kphgri 'ger $\mathrm{n} /$,

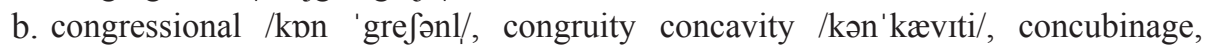
concordance /kpn'kə:dæt/, /kan'kjubənıdz//kpn 'gru:əti/, conglomerate, /kən 'glpmərit/,

c. concubine /'kaykju, bain/, congress /'kpygres/, concord /'kppko:d/, concrete /'kpj-/ conclave, /'kpykleıv; 'kpn-/ congregate, /'kpygrigert/

d. conger /'kph-/

As can be seen, assimilation is practically obligatory with the tonic syllable, and does not occur in post stress positions as Chomsky, Halle, Hoard, Anderson and Jones observed. Secondary stress also seems to play a role (cf. 4a). The realizations of the native speaker recording confirmed such velar/alveolar nasal distribution.

Regarding the collected data, several questions need to be answered. This research concentrates only on two:

(i) why does only velar articulation block assimilation in Latinate vocabulary with $\{$ in $\}$, that is, why do traditionally 'cohering' prefixes tend not to cohere to the velar POA? (This question, it is worth noting, has to the best of my knowledge never been asked by generative phonology).

(ii) assuming that stress can help eliminate the morphological boundary and trigger assimilation in a stress-based language, why does some portion of the data show a difference in the assimilating context, that is, with the voiceless stop following, the assimilation was admitted as an option, while with the voiced one - there was no assimilation whatsoever. ${ }^{12}$

One explanation of why assimilation occurred freely, as in imply, comply, irrelevant, and correlative, but was blocked or at least problematic in e.g. congressional, syncope, panchronic, ingratiate, could be purely diachronic, although I admit, at this stage of the research there are not enough data to establish this. However, if we suppose that all Latinate vocabulary was borrowed into English as already assimilated, then we could assume that English phonology did not do practically anything in this respect. That is, 'autochthon' English phonology has only one higher order instruction: to observe prefix boundary and block assimilation. ${ }^{13}$ The difference in the assimilation pattern with regard to the velar assimilation also can be accounted for by positing that if the vocabulary transfer in Middle English period was carried mainly through the superstrata language - formal documents as in writing - then the velar assimilation was the only assimilation type which could not be recovered by English users of the lexemes, due to the fact that Latin lacked a separate symbol for the velar nasal sound. The morphological boundary as in e.g. concave was still somehow present, which is the reason that, wherever the graphic sign did not indicate otherwise, speakers

${ }_{12}$ Reiterating the caveat, the majority of dictionaries showed no difference at all. The most frequent dictionary (also online) representation, and recordings of my native speakers show the lack of assimilations in \{in-\} prefixations. On the other hand, using the dictionaries gave me possibility to access to wider range of possible options, which would not be available in the case of recordings of single speakers.

${ }^{13}$ This is actually what Zabrocki slightly seems to imply when he mentions that e.g. in Latin there was obligatory nasal POA, while in Germanic languages - there was not. Also, Zabrocki at some point admits, that the $/ \mathrm{h} /$ before the nasal (as in e.g. cohering) must has been lost already in Vulgar Latin. 
incorporate morphological information in the realization (as lack of nasal POA assimilation in e.g. incongruent).

Regardless of these issues, questions i) and ii) find an easy solution when the results are checked against the predictions of Zabrocki's structural phonetics. Let us recall from the previous section that Zabrocki motivated certain preferences for the stability of the nasal element on two planes (synchronic and diachronic). Looking at Figure 2 (right), we can see that there is a difference between the structural position of velar stops and velar nasals and the remaining articulations. Due to the larger articulatory mass, ${ }^{14}$ which directly translates into the ratio between the two resonators, velar articulations are the most stable hosts and 'neighbours' for sustaining nasality. Hence, the fact that the assimilations did not occur precisely in this codal area while they underwent in the remaining one, strongly supports Zabrocki's findings.

However, gradation also occurs in another dimension. There is a question why in a portion of the dictionary sources there is a difference in the assimilation with the $\{$ in- $\}$ prefix, that is, the assimilation was allowed as an option under primary stress when the nasal preceded a voiceless stop. Within each articulatory group, the stability of the nasal element before a voiced segment was greater than before voiceless segments. As we can recall, Zabrocki established that all Indo-European languages where the nasal segment disappeared confirmed the systemic predictions: the voiceless segments exert a more unpropitious influence on nasal segments than voiced ones, mainly due to the fact that nasals are mainly phonetically voiced sounds. This means that if the nasal segment disappeared diachronically in particular languages, the elision started with the voiceless environments and then proceeded to voiced ones.

It must be recalled that from a Natural Phonology perspective all POA assimilations are lenitions - processes serving the speaker. Hence, velar assimilation in prefixes can be seen as a lenition - a weakening of the basic form and a weakening of the morphological boundary. The gradational aspect can be singled out as follows: all English Latinate vocabulary has been subjected to assimilatory processes in the donor language, or rather, already by the Vulgar Latin times. However, due to some cognitive and perhaps semantic factors (the need to signal negation in language), during the process of elimination, the elision of morphological boundary was more advanced \{con-, syn-, pan- $\}$, while the boundary was active with a semantically contentful prefix $\{$ in- $\}$. Synchronically this preference is parameterized in complete accordance with Zabrocki's tenets: with group 1 (\{con-, syn-, pan- $\}$ ), the assimilation is sensitive both to secondary and primary stress, while the voicing status of the following vowel is unimportant. With another group $\{$ in- $\}$, sensitivity is an option only in the following voiceless context: no process is active in careful speech in voiced velars. The remaining prefixes (in nonce sequences, such as Mr Phongraff, rhinegress) do not show

${ }^{14}$ The difference of the articulatory masses has been corroborated independently. E.g. Král' \& Sabol (1986) give the following insights on the articulation of angma: The consonant $\mathrm{y}$ "od aleolárnego $\mathrm{n}$ se líši okrem miesta artikulácie aj tym, že $y$ nemá fázu zrušenia ústneho záveru: mäkkopodniebný záver pretráva počas artikulácie obidvoch spouhlások (ng, nk). Na rozdiel od m, n záverový dotyk $\eta$ je širší než záverový dotyk k,g - rozširuje sa smerom dozadu" [angma differs from $/ \mathrm{n} /$ apart from the place of articulation also due to the fact, that there is not a phase of the withdrawal of the oral occlusion: the closure of the soft palate lasts during the articulation of both consonants (ng, nk). In contrast to $\mathrm{m}, \mathrm{n}$, the occlusive touch of $\mathrm{y}$ is wider [than $\mathrm{k}, \mathrm{g}$ ]: it extends rearwards]" (Král \& Sabol 1986: 227). 
any assimilation. It must also be remembered that $\{$ un- $\}$ is never under primary stress in English, hence it cannot be compared; however, it should be emphasized that nothing in the data points to its synchronic cognitive status being any different from $\{$ in- $\}$ where the semantic content is still extractable. Due to the lack of context with primary stress, the two cannot be compared.

Summing up, the discussion showed the explanatory power of Zabrocki's structural phonetics, by means of which several seemingly unrelated phenomena could be coherently explained. Moreover, some areas of English prefixation were addressed that have been generally neglected by scholars in the past, albeit some of them merit definitely further fine-grained investigation. The conclusion suggested is that English prefixation is an intricate topic, largely surpassing and running counter to the cohering-non-cohering dichotomy (canonically epitomized by $\{$ un- $\}$ and $\{$ in- $\}$ ). The data points to the fact that $\{$ in- $\}$ seems in fact closer to $\{$ un- $\}$ than $\{$ con- $\}$ - and not only with respect to the velar POA assimilation, but also to synchronically active sequences with directional meaning, as in inmate, inborn, input, ingoing.

\section{References}

Anderson, John \& Jones, Charles. 1977. Phonological structure and the history of English. Amsterdam: NorthHolland Publishing Company.

Awedyk, Wiesław. 2007. Zabrocki on sound change: Discussion. Paper presented at the 38th Poznań Linguistic Meeting, 13-16 September 2007, Gniezno.

Awedyk, Wiesław. 1975. Palatal Umlaut versus Velar Umlaut and Breaking. Poznań: UAM Press.

Bańczerowski, Jerzy (ed.). 1980. Ludwik Zabrocki: U podstaw struktury i rozwoju języka [Ludwik Zabrocki: At the foundation of language structure and development]. Warszawa: PWN.

Bańczerowski, Jerzy. 1980. Ludwik Zabrocki as a theorist of language. In Bańczerowski Jerzy (ed.), Ludwik Zabrocki: U podstaw struktury i rozwoju języka [Ludwik Zabrocki: At the foundation of language structure and development], 10-22. Warszawa: PWN.

Booij, Geert. 2012[2005]. The grammar of words. An introduction to morphology. Oxford: OUP.

Carr, Philip. 1993. Phonology. London: Macmillan.

Chomsky, Noam \& Halle, Morris. 1968. The sound pattern of English. New York: Harper and Row.

Chornohor, Yulia. 2007. On morphophonological categorization of suffixes in English stress. System und Variation 29. 187-188.

Haładewicz-Grzelak, Małgorzata submitted. Beats-and-Binding topics in the (mor)phonology of \{con-\}.

Haładewicz-Grzelak, Małgorzata. 2014. Reanalysis and saliency in English Latinate prefixation: a case study of the prefixal POA assimilation in English. In: Bulletin de la société polonaise de la linguistique LXX. 79-93.

Hoard, James. 1971. Aspiration, tenseness and syllabification in English. Language 47(1). 133-140.

Král', Ábel \& Sabol, Ján. 1986. Fonetika a fonológia. Bratislava: Slovenské pedagogické Nakladatel’stvo.

Ohala, John \& Ohala, Manjari. 1993. The phonetics of nasal phonology: theorems and data. In Huffman, Marie K. \& Krakow, Rena (eds.), Nasals, nasalization and the Velum, 225-249. San Diego: Academic Press.

Scheer, Tobias. 2011. A guide to morphosyntax-phonology interface theories. Berlin: Mouton de Gruyter.

Rakić, Stanimir. 2007. A note on the latinate constraint in English affixation. Journal of Theoretical Linguistics 4(3). 45-56. http://www.skase.sk/Volumes/JTL10/pdf_doc/4.pdf.

Zabrocki, Ludwik. 1960[1980]. Zagadnienia fonetyki strukturalnej [Problems of structural phonetics]. Sesja Naukowa Komisji Filologicznej. Poznań: Polskie Towarzystwo Przyjaciół Nauk, 165-185. Reprinted in Bańczerowski (ed.), Ludwik Zabrocki: U podstaw struktury i rozwoju języka [Ludwik Zabrocki: At the foundation of language structure and development], 52-74. Warszawa: PWN.

Zabrocki, Ludwik. 1962[1981]. Stabilność spółgłosek nosowych w rozwoju historycznym [The stability of nasal consonants in the diachronic development]. In Bańczerowski (ed.), Ludwik Zabrocki: U podstaw struktury $i$ rozwoju jezzka [Ludwik Zabrocki: At the foundation of language structure and development], $192-243$. Warszawa: PWN. Reprint from: Lingua Posnaniensis 9. 44-97. 